ppłk dr inż. Paweł Maciejewski ${ }^{1}$

płk dr inż. Waldemar Robak ${ }^{2}$

ppłk dr inż. Mariusz Młynarczyk ${ }^{1}$

Przyjęty/Accepted/Принята: 17.01.2014;

Zrecenzowany/Reviewed/Рецензирована: 22.11.2014;

Opublikowany/Published/Опубликована: 31.03.2015;

\title{
Indywidualne środki ochrony przed skażeniami w Wojsku Polskim ${ }^{3}$
}

\author{
Protection from CBRN Contamination in the Polish Armed Forces
}

\author{
Средства индивидуальной защиты от загрязнений в Вооружённых Силах \\ Республики Польша
}

\begin{abstract}
A B S T R A K T
Cel: Celem publikacji jest przedstawienie zasadniczych parametrów indywidualnych środków ochrony przed skażeniami (ISOPS) stosowanych w Siłach Zbrojnych.

Wprowadzenie: W ostatnich dwóch dekadach w Wojsku Polskim nastąpił znaczący skok jakościowy w wyposażeniu indywidualnym żołnierzy, które służy do ochrony przed skażeniami. Sprzęt ten ukierunkowany jest głównie na ochronę przed skażeniami pochodzącymi od Broni Masowego Rażenia (BMR), ale można go wykorzystywać przy innych rodzajach skażeń. Przykładem takiego ekwipunku mogą być maski przeciwgazowe MP-5 i MP-6, w których można stosować filtropochłaniacze dedykowane do różnego rodzaju substancji niebezpiecznych. Z oczywistych względów Siły Zbrojne w czasie pokoju są szkolone i przygotowywane do zapewnienia właściwego poziomu ochrony wojsk i zwalczania skutków zdarzeń CBRN. Tymczasem Państwowa Straż Pożarna na co dzień zmaga się z zagrożeniami związanymi z uwolnieniami substancji niebezpiecznych. Niekiedy, w szczególności w sytuacji wystąpienia skażeń o wielkiej skali lub charakterze przekraczającym możliwości PSP, oczekuje się współdziałania obu podmiotów. Jedną z najważniejszych zasad współdziałania wojska i PSP jest zapewnienie bezpieczeństwa ratownikom uczestniczącym w działaniach, które w dużej mierze zależy od wzajemnego zrozumienia procedur, technik i możliwości wyposażenia występującego w obydwu formacjach. Jednocześnie czynniki te stanowią również determinanty efektu synergii, jeśli cywilne i wojskowe elementy ratownicze postrzegane są jako komponenty jednego, spójnego krajowego systemu.

Metodologia: W artykule zastosowano metodę analizy i krytyki piśmiennictwa oraz obserwacji. Autorzy bazowali przede wszystkim na instrukcjach fabrycznych producentów sprzętu oraz doświadczeniach użytkowników sprzętu.

Wnioski: W artykule zostało przedstawione najnowsze wyposażenie żołnierzy Wojska Polskiego, którzy w wyjątkowych sytuacjach będą wspierać inne elementy wykonawcze Systemu Zarządzania Kryzysowego kraju. Podstawą takiej współpracy będzie wzajemne zrozumienie procedur, technik i możliwości wyposażenia występującego w obydwu formacjach, a szczególnie możliwości realizacji zadań w warunkach skażeń przez poszczególne podmioty. Z powyższego wynika, że podczas wspólnego działania elementów wykonawczych reagowania kryzysowego w warunkach skażeń zasadnicze znaczenie dla skutecznego i bezpiecznego planowania, kierowania działań oraz ich realizacji będzie m.in. znajomość możliwości ochronnych indywidualnego wyposażenia uczestników (żołnierzy) w zakresie zagrożeń CBRN.
\end{abstract}

Słowa kluczowe: ochrona przed skażeniami, ISOPS, obrona przed zdarzeniami CBRN Typ artykułu: artykuł przeglądowy

\footnotetext{
Akademia Obrony Narodowej, Polska; p.maciejewski@aon.edu.pl / The National Defence University of Warsaw, Poland;

Centrum Szkolenia Wojsk Inżynieryjnych i Chemicznych im. gen. Jakuba Jasińskiego we Wrocławiu / Wrocław Engineering and Chemical Defence Troops Training Centre, Poland;

3 Wkład merytoryczny w powstanie artykułu / Percentage contribution: P. Maciejewski - 40\%, W. Robak - 30\%, M. Młynarczyk $-30 \%$;
} 


\section{A B S T R A C T}

Aim: The aim of the article is to present the essential parameters of personal protective measures against contamination, used by the Polish Armed Forces. Authors anticipate that exposed issues will improve the effective co-operation between services. Introduction: In the last two decades there was a significant qualitative leap in the provision of personal protection equipment to individual soldiers of the Polish Armed Forces. This equipment, in the main, is intended to provide protection against contamination from Weapons of Mass Destruction (WMD), but the equipment can also be used in other hazardous environments. An illustration of alternative uses may be found with MP-5 and MP- 6 respirators, which allow for the use of combined filters intended for use in the presence of all kinds of hazardous substances. For obvious reasons, military formations are trained and prepared to deal with consequential hazards associated with chemical, biological, radiological and nuclear (CBRN) warfare, and to secure an appropriate level of protection for military personnel. Simultaneously, the State Fire Service (SFS) struggles on a daily basis with hazards caused by the release of dangerous toxic substances. At times, specifically during major incidents or emergencies, which exceed the capability of SFS, both the Armed Forces and SFS are expected to co-operate and mitigate the consequences of a CBRN release. One of the most important principles of inter service co-operation concerns the safety of rescue personnel, which, to a large extent, depends on mutual understanding of procedures, techniques and availability of suitable equipment to both formations. These factors impact on synergy if civilian and military rescue elements are viewed as components of a single, unified national rescue system.

Method: This study contains a critical review of literature and includes outcomes from observation. In the main, the study utilized manufacturers' equipment instructions and information gained from user experience.

Conclusions: The article illustrates the latest equipment available to soldiers of the Polish Army who, in exceptional circumstances, support other formations involved with National Crisis Management System operations. The basis for such co-operation will be a mutual understanding of procedures, techniques, access to suitable equipment by both organisations and, in particular, the prospect of a successful discharge of responsibility in a hazardous environment by respective entities. From the aforementioned, it may be deduced that during joint rescue operations, the critical factor for safe and effective planning, management of operations and successful outcomes will be, inter alia, awareness of personal protective equipment potential, currently made available to personnel (soldiers) engaged in CBRN hazard operations.

Keywords: CBRN physical protection, CBRN personal protective equipment, CBRN defence, defence against CBRN hazards, force protection

Type of article: review article

\section{АННО ТАЦИЯ}

Цель: Целью публикации является представление основных параметров средств индивидуальной защиты от загрязнений (ISOPS), которые используются в Вооруженных Силах.

Введение: За последние два десятилетия в Вооруженных силах Республики Польша значительно повысилось качество средств индивидуального оборудования солдат, предназначенного для защиты от загрязнений. Данное оборудование направленно прежде всего на защиту от загрязнений, вызванных оружием массового поражения (ОМП), но оно также может использоваться при других видах загрязнений. Одним из таких примеров могут быть противогазы МР-5, МР-6, в которых можно использовать комбинированные фильтры, преданаченные для разного вида опасных веществ. По очевидным причинам Вооруженные силы в мирное время проходят обучение и подготовку для обеспечения ими соответствующего уровня защиты войск и ликвидации последствий химического, биологического, радиологического и ядерного оружия (ХБРЯ). Между тем, Государственная Пожарная Служба Республики Польша (PSP) ежедневно борится с угрозами, связанными с высвобождением опасных веществ. Иногда, особенно в ситуации крупномасштабного загрязнения или если его характер превышает возможности Государственной Пожарной Службы (PSP), ожидается сотрудничество обоих субъектов. Одним из важнейших принципов сотрудничества армии и Государственной Пожарной Службы (PSP) является обеспечение безопасности спасателям участвующим в действиях, которая в значительной степени зависит от обоюдного понимания процедур, техник и вариантов оснащения обеих групп. В то же время эти факторы являются определяющими во взаимодействии, если гражданские и военные спасательные элементы рассматриваются как компоненты единой, согласованной национальной системы.

Методология: В статье использован метод анализа и критики литературы, а также наблюдений. Авторы принимали за основу заводские инструкции производителей и опыт пользователей данного оборудования.

Выводы: В статье было представлено современное оснащение солдат Вооруженных сил Республики Польша, которые в чрезвычайных ситуациях будут поддерживать другие исполнительные субъекты Системы Кризисного Управления страны. Основой такого сотрудничества будет взаимное понимание процедур, техник и возможностей оборудования обеих формаций, в частности возможность выполнения задач в условиях загрязнений отдельными субъектами. Из вышеприведенного следует, что во время совместного действия исполнительных субъектов кризисного реагирования в условиях загрязнений основное значение для эффективного и безопасного 
планирования, управления действиями а также их реализации будет иметь знание о защитных возможностях индивидуальных средств защиты участников (солдат) в сфере угроз химического, биологического, радиологического и ядерного характеров (ХБРЯ).

Ключевые слова: защита от загрязнений, средства индивидуальной защиты от загрязнений (ISOPS), защита от XБРЯ Вид статьи: обзорная статья

\section{Wprowadzenie}

Katastrofy naturalne i cywilizacyjne oraz niekiedy towarzyszące im skażenia chemiczne, promieniotwórcze i biologiczne wymagają podjęcia działań ratowniczych przez odpowiednio przygotowane siły posiadające specjalistyczne wyposażenie. Organizacja działań ratowniczych a następnie usuwanie skutków powstałych skażeń, wymagać może zaangażowania dostępnych sił i środków (adekwatnie do skali zdarzenia), wchodzących w skład Systemu Zarządzania Kryzysowego, a w szczególnych wypadkach także niewchodzących w skład Systemu. Zgodnie $\mathrm{z}$ ideą funkcjonowania systemu [1], w sytuacji gdy środki te okażą się niewystarczające, istnieje możliwość użycia potencjału Sił Zbrojnych RP [2, 3, 4]. $\mathrm{Z}$ tego względu w celu optymalnego wykorzystania dostępnych zasobów należy konsekwentnie i bezkompromisowo dążyć do osiągnięcia efektu synergii, pamiętając jednocześnie o obowiązku przećwiczenia wcześniej zaplanowanych działań. Zadecyduje to bowiem o tzw. zgraniu całego systemu, odzwierciedlającego poziom uzyskanej synergii. Pomimo iż nie sposób przygotować się na wszelkie antycypowane zagrożenia, z pewnością można określić właściwe procedury działania, opierające się przede wszystkim na znajomości realnych możliwości dostępnych sił i środków elementów wykonawczych, ze szczególnym uwzględnieniem ograniczeń $w$ tym zakresie. W obszarze ratownictwa chemiczno-ekologicznego bez wątpienia pierwszoplanową rolę odgrywa Krajowy System Ratowniczo-Gaśniczy, który w razie konieczności otrzyma niezbędne wsparcie. Istotę bezpiecznej współpracy $\mathrm{w}$ tym przypadku stanowi wiedza o potencjale drugiej strony, przede wszystkim w zakresie dostępnych zasobów, sił i środków, poziomu wyszkolenia i procedur działania oraz wyposażenia ochronnego i ratowniczego. O ile kierujący akcją ratowniczą będzie znał doskonale możliwości własnych elementów wykonawczych (Państwowej Straży Pożarnej, wspieranych przez Specjalistyczne Grupy Ratownictwa Chemiczno-Ekologicznego [5, 6]), o tyle mogą wystąpić trudności w zakresie sprawnego i pełnego wykorzystania potencjału elementów wspierających (współpracujących) wydzielonych przez SZ RP. Świadomość zasad ich użycia wydaje się być niezbędna do racjonalnego i zgodnego z przeznaczeniem wykorzystania całości sił i środków znajdujących się w dyspozycji kierującego akcją ratowniczą. Wychodząc $z$ założenia, że zapewnienie właściwej ochrony zasobów uczestniczących w akcji ratowniczej warunkuje ich sprawne i przede wszystkim bezpieczne działanie, $w$ niniejszym artykule skoncentrowano się wyłączne na standardowych, indywidualnych środkach ochrony przed skażeniami, znajdujących się na wyposażeniu Sił Zbrojnych RP. W kolejnej publikacji zaprezentowane zostaną możliwości wojskowego podsystemu ratownictwa ze szczególnym uwzględnieniem pododdziałów wojsk chemicznych, na bazie których tworzone są Chemiczno-Radiacyjne Zespoły Awaryjne [7, 8].

\section{Indywidualna ochrona przed skażeniami w wojsku}

Indywidualna ochrona przed skażeniami w wojsku to działalność polegająca na wyposażeniu każdego żołnierza w maskę przeciwgazową oraz izolacyjne lub filtracyjne środki ochrony skóry celem zapewnienia mu bezpieczeństwa podczas realizacji zadań w warunkach zagrożenia skażeniami lub skażeń. Indywidualne środki ochrony przed skażeniami (ISOPS) obejmują:

a) sprzęt dozymetryczny,

b) maskę przeciwgazową i odzież ochronną,

c) środki do udzielania pierwszej pomocy,

d) indywidualne pakiety do likwidacji skażeń [9].

Na początku XXI wieku w Wojsku Polskim nastąpił technologiczny przełom w zakresie indywidualnej ochrony przed skażeniami. Maski MP-4 i SzM-41 zostały zastąpione nowoczesną maską MP-5, a izolacyjna odzież ochronna OP-1 - odzieżą filtracyjną FOO-1. Zmieniło się także pojmowanie pojęcia ISOPS. Wprowadzona w 2004 r. doktryna obronna DD/3.8 (znowelizowana w 2014 r. [9]) rozszerzyła to pojęcie o indywidualne pakiety do likwidacji skażeń, środki do udzielania pierwszej pomocy i sprzęt dozymetryczny. Zmiany te ustanowiły nową jakość $\mathrm{w}$ indywidualnej ochronie żołnierza przed skażeniami oraz wymusiły zmiany w sposobie eksploatacji tych środków, a co za tym idzie - w szkoleniu żołnierzy w ich użytkowaniu. 
Aktualnie w SZ RP stosuje się następujące ISOPS:

a) sprzęt dozymetryczny:

- dawkomierz indywidualny SOR/T-012,

b) maski przeciwgazowe i odzież ochronną:

- filtracyjną maskę przeciwgazowa MP-5 i MP-6,

- lekką izolacyjną odzież ochronną LIOO-1,

- filtracyjną odzież ochronną FOO-1 oraz uzupełniająca ją,

- narzutkę ochronna NO-1,

c) środki do udzielania pierwszej pomocy:

- indywidualny pakiet medyczny żołnierza (IPMed), d) indywidualne pakiety do likwidacji skażeń:

- indywidualny pakiet do likwidacji skażeń IPLS-1.

\subsection{Sprzęt dozymetryczny}

Dawkomierz elektroniczny SOR/T (ryc. 1) przeznaczony jest do pomiaru promieniowania gamma i neutronowego: impulsowego (w czasie wybuchu jądrowego, w trybie ręcznym) oraz wtórnego gamma (promieniowanie wtórne - od opadu promieniotwórczego lub innych źródeł promieniotwórczych, w trybie zdalnym).

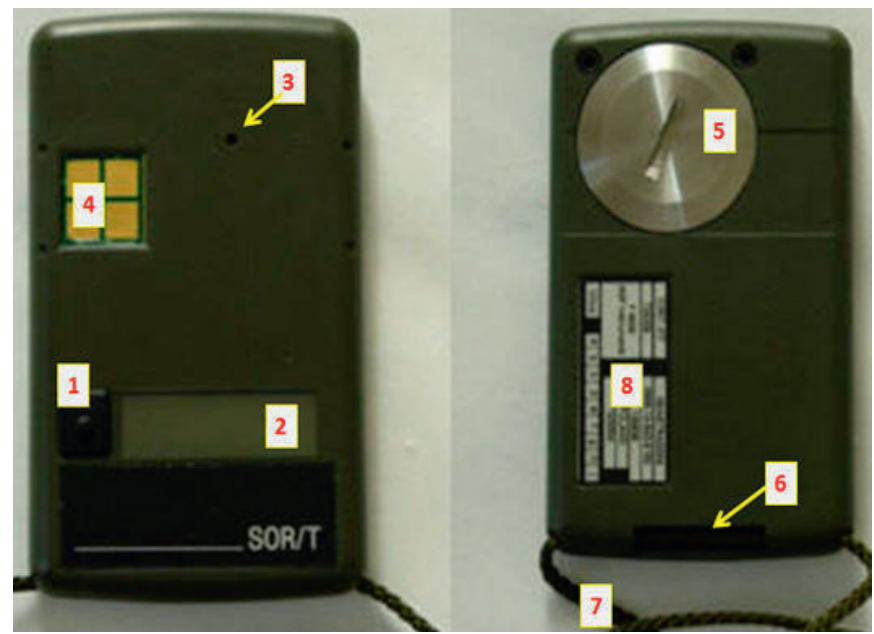

Ryc. 1. Dawkomierz indywidualny SOR/T - widok z przodu (z lewej) i z tyłu

1 - przycisk (włącznik, sterowanie), 2 - wyświetlacz (6 pól), 3 - brzęczyk, 4 - złącze elektroniczne, 5 - pokrywa baterii,

6 - miejsce na zamocowanie klipsa, 7 - sznurek do przenoszenia na szyi, 8 - tabliczka znamionowa

Fig. 1. Personal individual dosimeter SOR/T - front view (from the left) and back view

1- button (turn on, steering), 2 - display (6 signs), 3 - sound signal, 4 - electronic connection, 5 - battery's cover, 6 - clip, 7 - neck lanyard

Źródło: Opracowanie własne.

Source: Own elaboration.

Dawkomierz ma szczelną obudowę chroniącą zarówno przed cieczami, jak i przed pyłem. W górnej części obudowy znajduje się otwór do zamocowania klipsa oraz otwory na sznurek nośny, który można szybko podłączyć za pomocą zatrzasku.

Konfiguracja dawkomierza odbywa się przy użyciu czytnika XOM/T-012 (jeden na szczeblu pododdziału), natomiast odczyt jest możliwy w dwóch trybach: ręcznym (Manual mode) lub zdalnym (Hands free mode). Uwaga! Odczyt w trybie zdalnym jest możliwy, gdy odległość dawkomierza od czytnika nie przekracza $40 \mathrm{~cm}$. Tryb zdalny umożliwia przekazywanie danych zarejestrowanych przez dawkomierz (numer dawkomierza, tożsamość użytkownika, zarejestrowane dawki, numer identyfikacyjny i nazwisko). Tryb ręczny umożliwia użytkownikowi odczyt wybranych informacji.

Dane taktyczno-techniczne:

- temperatura pracy: od $-40^{\circ} \mathrm{C}$ do $+50^{\circ} \mathrm{C}$,

- wymiary: 80,4 x $48 \times 9,2 \mathrm{~mm}$,

- waga: $50 \mathrm{~g}$,
- czas pracy na jednej baterii: 9 miesięcy, (pomiar - impulsowe promieniowanie gamma i neutronowe podczas wybuchu jądrowego)

- zakres pomiarowy impulsu promieniowania gamma i neutronowego: $5 \mathrm{cGy}-10 \mathrm{~Gy}$,

- dokładność pomiaru $\pm 30 \%$,

- zakres energii do $14 \mathrm{MeV}$ (dla promieniowania neutronowego),

(pomiar - wtórne promieniowanie gamma - z opadu promieniotwórczego, broni radiologicznej lub innych źródeł promieniowania jonizującego)

- zakres pomiarowy dawki - od poziomu tła do $10 \mathrm{~Gy}$,

- zakres pomiarowy mocy dawki - od $1 \mu \mathrm{Gy} / \mathrm{h}$ do $10 \mathrm{~Gy} / \mathrm{h}$,

- pomiar promieniowania $\mathrm{w}$ przedziale energetycznym - od $50 \mathrm{keV}$ do $6 \mathrm{MeV}$,

- dokładność pomiarów $< \pm 5 \% \mathrm{w}$ całym zakresie pomiarowym od źródła Cs-137. 
Szczegółowe dane zamieszczono w instrukcji fabrycznej. Jak dotychczas nie wydano instrukcji wojskowej.

\subsection{Maski przeciwgazowe}

Filtracyjne maski przeciwgazowe MP-5 i MP-6 przeznaczone są do ochrony dróg oddechowych, oczu i twarzy żołnierza przed bojowymi środkami trującymi (BST), aerozolami biologicznymi oraz pyłem promieniotwórczym (ryc. 2). Wymagany czas nałożenia dla obu masek do położenia bojowego wynosi do $9 \mathrm{~s}$, a ich czas ochronnego działania $\mathrm{w}$ rejonie skażonym aerozolami BST to minimum 24 godziny. Omawiane maski ze standardowym filtropochłaniaczem są jednak mniej skuteczne w ochronie przed toksycznymi środkami przemysłowymi (TSP), a szczególnie wobec toksycznych środków chemicznych (TSC) stosowanych $\mathrm{w}$ przemyśle, a które $\mathrm{w}$ przeciwieństwie do środków bojowych $\mathrm{z}$ reguły będą występować $\mathrm{w}$ atmosferze w dużych stężeniach. Dlatego w przypadku takich skażeń trzeba stosować selektywne lub wielogazowe filtropochłaniacze (tab. 1), odpowiednie do konkretnych TSC. Przedstawiony wykaz filtropochłaniaczy dotyczy oferty dla użytkowników „cywilnych”.
W konstrukcji maski MP-6 uwzględniono wnioski wypływające $\mathrm{z}$ eksploatacji MP-5 $\mathrm{w}$ celu poprawy parametrów użytkowych i ochronnych. Aby ułatwić obsługiwanie broni, filtropochłaniacz można podłączyć do części twarzowej z lewej lub prawej strony. Takie rozwiązanie umożliwia również podłączenie dwóch filtropochłaniaczy, przez co zwiększa się ergonomia maski dzięki obniżeniu oporu przepływu powietrza, co jest szczególnie istotne $\mathrm{w}$ działaniach bojowych wymagających zwiększonego zapotrzebowania na tlen, np. podczas intensywnego wysiłku. Okulary maski wykonano z poliwęglanu o właściwościach odłamkoodpornych, a ich uzupełnienie stanowią dodatkowe, nakładane filtry, np. przed światłem lasera. Maska MP-5 dostępna jest czterech, a maska MP- 6 - w trzech rozmiarach zapewniających ich szczelne dopasowanie do różnych kształtów twarzy. Ponadto umożliwiają pobieranie płynów bez konieczności zdejmowania maski. Szczegółowe dane dostępne są w instrukcjach fabrycznych oraz w Instrukcji filtracyjnej maski przeciwgazowej MP-5, Chem. 399/2007. Jak dotychczas nie wydano instrukcji wojskowej maski MP-6.

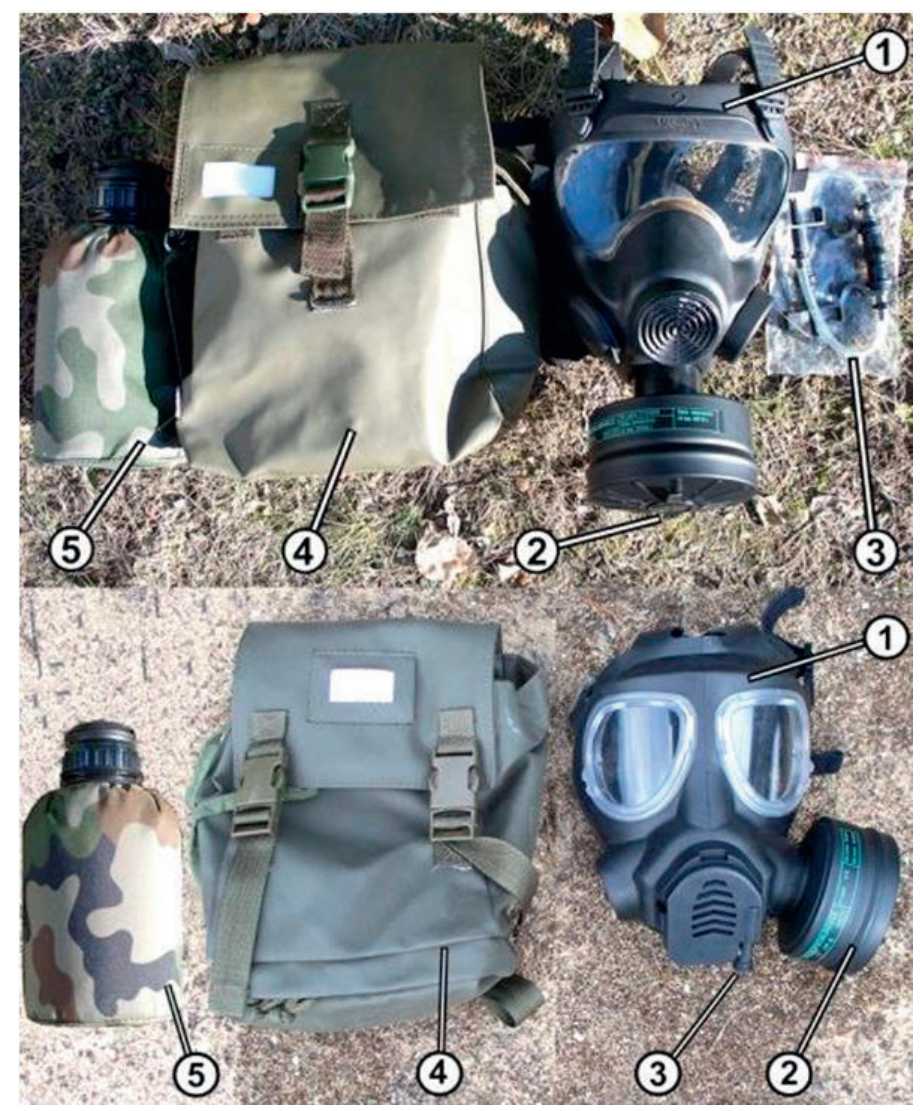

Ryc. 2. Maska przeciwgazowa MP-5 (góra) i MP-6

1 - część twarzowa z nagłowiem taśmowym, 2 - filtropochłaniacz, 3 - urządzenie do przyjmowania płynów, 4 - torba nośna, 5 - manierka

Fig. 2. Gas mask MP-5 (upper part) and MP-6

1 - facial part of the headgear belt, 2 - filter, 3 - drinking device, 4 - carrying bag, 5 - container for drinking device Źródło: Opracowanie własne. Source: Own elaboration. 
Należy podkreślić istotny, a często pomijany, fakt, że filtracyjna maska przeciwgazowa, jak sama nazwa wskazuje, oczyszcza powietrze, ale nie wytwarza tlenu! Dlatego można ją stosować pod warunkiem, że w atmosferze znajduje się, co najmniej 17\% tlenu. Należy zachować również ostrożność w stosowaniu maski filtracyjnej w czasie pożarów przestrzennych, szczególnie podczas wchodzenia do palących się pomieszczeń (obniżony poziom tlenu). Ponadto standardowy filtropochłaniacz nie chroni przed tlenkiem węgla (czadem), który powstaje podczas pożarów.

Tabela 1. Wykaz filtropochłaniaczy selektywnych i wielogazowych Table 1. List of selective and multi-gas filters

\begin{tabular}{|c|c|c|c|c|c|}
\hline \multirow[b]{2}{*}{ Lp. } & \multirow{2}{*}{$\begin{array}{l}\text { Rodzaj czynnika szkodliwego } \\
\text { Type of harmful factor }\end{array}$} & \multicolumn{2}{|c|}{$\begin{array}{l}\text { Oznaczenie filtropochłaniacza } \\
\text { Indication of filter }\end{array}$} & \multirow{2}{*}{$\begin{array}{c}\text { Dopuszczalne } \\
\text { stężenie objętościowe } \\
\text { Acceptable volume } \\
\text { concentration }\end{array}$} & \multirow{2}{*}{$\begin{array}{c}\text { Typ } \\
\text { i klasa } \\
\text { Type and } \\
\text { class }\end{array}$} \\
\hline & & $\begin{array}{c}\text { Barwa naklejki } \\
\text { Color of the } \\
\text { sticker }\end{array}$ & $\begin{array}{l}\text { Symbol } \\
\text { Symbol }\end{array}$ & & \\
\hline \multirow[t]{2}{*}{1} & $\begin{array}{c}\text { Organiczne pary i gazy o temp. wrzenia } \\
\text { powyżej } 65^{\circ} \mathrm{C} \\
\text { Organic gases and vapors with a boiling point } \\
\text { above } 65^{\circ} \mathrm{C}\end{array}$ & $\begin{array}{l}\text { BRAZZOWA } \\
\text { BROWN }\end{array}$ & \multirow[t]{2}{*}{ FP 211/1-P3/A } & $0,5 \%$ & $\mathrm{~A} 2$ \\
\hline & $\begin{array}{c}\text { Pyły i aerozole } \\
\text { Dusts and aerosols }\end{array}$ & $\begin{array}{l}\text { BIAŁA } \\
\text { WHITE }\end{array}$ & & & P3 \\
\hline \multirow[t]{2}{*}{2} & $\begin{array}{l}\text { Nieorganiczne pary i gazy } \\
\text { (z wyjątkiem tlenku węgla) } \\
\text { Inorganic gases and vapors } \\
\text { (except for carbon monoxide) }\end{array}$ & $\begin{array}{l}\text { SZARA } \\
\text { GREY }\end{array}$ & \multirow[t]{2}{*}{ FP 211/1-P3/B } & $0,5 \%$ & B2 \\
\hline & $\begin{array}{c}\text { Pyły i aerozole } \\
\text { Dusts and aerosols }\end{array}$ & $\begin{array}{l}\text { BIAŁA } \\
\text { WHITE }\end{array}$ & & & P3 \\
\hline \multirow{2}{*}{3} & $\begin{array}{l}\text { Dwutlenek siarki i inne kwaśne pary i gazy } \\
\text { Sulfur dioxide and other acid gases and vapors }\end{array}$ & $\begin{array}{l}\text { ŻÓŁTA } \\
\text { YELLOW }\end{array}$ & \multirow{2}{*}{ FP 211/1-P3/E } & $0,5 \%$ & E2 \\
\hline & $\begin{array}{c}\text { Pyły i aerozole } \\
\text { Dusts and aerosols } \\
\end{array}$ & $\begin{array}{l}\text { BIAŁA } \\
\text { WHITE }\end{array}$ & & & P3 \\
\hline \multirow{2}{*}{4} & $\begin{array}{l}\text { Amoniak i pochodne organiczne amoniaku } \\
\text { Ammonia and organic ammonia derivatives }\end{array}$ & $\begin{array}{l}\text { ZIELONA } \\
\text { GREEN }\end{array}$ & \multirow{2}{*}{ FP 211/1-P3/K } & $0,5 \%$ & $\mathrm{~K} 2$ \\
\hline & $\begin{array}{c}\text { Pyły i aerozole } \\
\text { Dusts and aerosols } \\
\end{array}$ & $\begin{array}{l}\text { BIAŁA } \\
\text { WHITE }\end{array}$ & & & P3 \\
\hline \multirow{2}{*}{5} & $\begin{array}{l}\text { Tlenki azotu } \\
\text { Nitrogen oxides }\end{array}$ & $\begin{array}{l}\text { NIEBIESKA } \\
\text { BLUE }\end{array}$ & \multirow{2}{*}{$\mathrm{FP} 211 / 1-\mathrm{P} 3 / \mathrm{NO}$} & $0,25 \%$ & $\mathrm{NO}$ \\
\hline & $\begin{array}{c}\text { Pyły i aerozole } \\
\text { Dusts and aerosols }\end{array}$ & $\begin{array}{l}\text { BIAŁA } \\
\text { WHITE }\end{array}$ & & & P3 \\
\hline \multirow{2}{*}{6} & $\begin{array}{c}\text { Pary rtęci } \\
\text { Mercury vapor }\end{array}$ & $\begin{array}{l}\text { CZERWONA } \\
\text { RED }\end{array}$ & \multirow{2}{*}{ FP $211 / 1-\mathrm{P} 3 / \mathrm{Hg}$} & $1,6 \mathrm{ml} / \mathrm{m} 3$ & $\mathrm{Hg}$ \\
\hline & $\begin{array}{c}\text { Pyły i aerozole } \\
\text { Dusts and aerosols }\end{array}$ & $\begin{array}{l}\text { BIAŁA } \\
\text { WHITE }\end{array}$ & & & $\mathrm{P} 3$ \\
\hline \multirow{5}{*}{7} & $\begin{array}{l}\text { Organiczne pary i gazy o temp. wrzenia } \\
\text { powyżej } 65^{\circ} \mathrm{C} \\
\text { Organic gases and vapors with a boiling } \\
\text { point above } 65^{\circ} \mathrm{C}\end{array}$ & $\begin{array}{l}\text { BRAZZOWA } \\
\text { BROWN }\end{array}$ & \multirow{5}{*}{ FP 211/1-P3/W } & $0,5 \%$ & $\mathrm{~A} 2$ \\
\hline & $\begin{array}{l}\text { Nieorganiczne pary i gazy } \\
\text { (z wyjątkiem tlenku węgla) } \\
\text { Inorganic gases and vapors } \\
\text { (except for carbon monoxide) }\end{array}$ & $\begin{array}{l}\text { SZARA } \\
\text { GREY }\end{array}$ & & $0,5 \%$ & B2 \\
\hline & $\begin{array}{l}\text { Dwutlenek siarki i inne kwaśne pary i gazy } \\
\text { Sulfur dioxide and other acid gases and vapors }\end{array}$ & $\begin{array}{l}\text { ŻÓŁTA } \\
\text { YELLOW }\end{array}$ & & $0,5 \%$ & E2 \\
\hline & $\begin{array}{l}\text { Amoniak i pochodne organiczne amoniaku } \\
\text { Ammonia and organic ammonia derivatives }\end{array}$ & $\begin{array}{l}\text { ZIELONA } \\
\text { GREEN }\end{array}$ & & $0,5 \%$ & $\mathrm{~K} 2$ \\
\hline & $\begin{array}{c}\text { Pyły i aerozole } \\
\text { Dusts and aerosols }\end{array}$ & $\begin{array}{l}\text { BIA£A } \\
\text { WHITE }\end{array}$ & & & P3 \\
\hline
\end{tabular}

Źródło: Maskpol S.A. Katalog sprzętu ochronnego Source: Maskpol S.A. Protective equipment catalog 


\subsection{Odzież ochronna}

\subsubsection{Lekka izolacyjna odzież ochronna}

Lekka izolacyjna odzież ochronna LIOO-1 (w komplecie $\mathrm{z}$ maską przeciwgazową) przeznaczona jest do ochrony skóry i układu oddechowego użytkownika przed działaniem BST oraz TSP (w tym biologicznych), występujących w powietrzu w postaci par, aerozoli, pyłu, kropel. Ponadto stanowi skuteczną barierę dla promieniowania alfa oraz częściową
- przed promieniowaniem beta. Odzież wykonano $\mathrm{z}$ materiału barierowego TYVEK F (który posiada właściwości samogasnące) i dostępna jest w trzech rozmiarach, a jej masa w opakowaniu wynosi ok. 1,5 kg. LIOO-1 została tak zaprojektowana, aby można ją było swobodnie nałożyć na mundur i obuwie oraz zapewnić minimum 12 godzin ochrony przed BST. Szczegółowe dane zamieszczono w instrukcji fabrycznej. Jak dotychczas nie wydano instrukcji wojskowej.

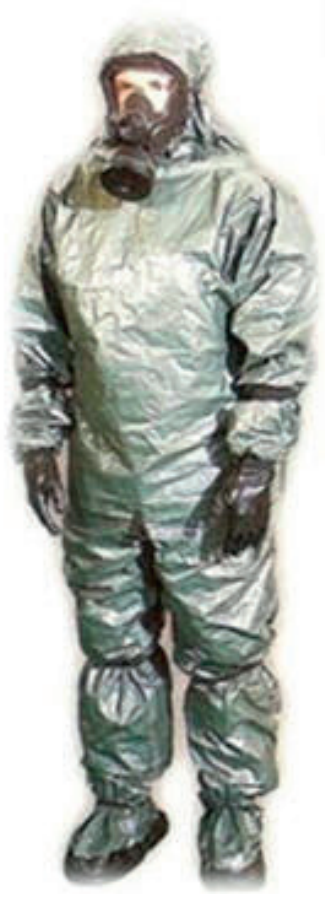

Ryc. 3. Lekka izolacyjna odzież ochronna LIOO-1

1 - bluza z kapturem, 2 - rękawice gumowe z wkładem ocieplającym, 3 - spodnie z kaloszami

Fig. 3. Lightweight insulating protective clothing LIOO-1

1 - hooded sweatshirt, 2 - warming gloves, 3 - pants and galoshes

Źródło: Opracowanie własne.

Source: Own elaboration.

\subsubsection{Filtracyjna odzież ochronna FOO-1}

Filtracyjna odzież ochronna FOO-1 (łącznie $\mathrm{z}$ maską przeciwgazową) przeznaczona jest do indywidualnej ochrony żołnierza przed skażeniami chemicznymi, biologicznymi i promieniotwórczymi, występującymi w powietrzu w postaci par, aerozoli i pyłów. Ponadto stanowi skuteczną barierę dla promieniowania alfa oraz częściową - dla promieniowania beta. Ubranie zastępuje, przy temperaturze powietrza powyżej $5^{\circ} \mathrm{C}$, mundur polowy i może być wkładane bezpośrednio na bieliznę. Poniżej $5^{\circ} \mathrm{C}$ FOO-1 należy wkładać na dres lub bezpośrednio na mundur polowy. Celem poprawy ochrony przed ciekłymi środkami trującymi oraz opadem promieniotwórczym na FOO-1 należy dodatkowo założyć narzutkę ochronną. Ubranie wykonane jest w sześciu, a buty i rękawice w trzech rozmiarach, co zapewnia optymalny komfort użytkownikowi. $\mathrm{W}$ temperaturze otoczenia poniżej $18^{\circ} \mathrm{C}$ odzież użytkuje się jak ubranie polowe, a czas pracy w odzieży limitują jedynie przerwy na odpoczynek. Powyżej $18^{\circ} \mathrm{C}$ liczba odpoczynków powinna być zwiększona, podobnie jak czas ich trwania w porównaniu z użytkowaniem zwykłego munduru polowego, ponieważ FOO-1 gorzej odprowadza ciepło i pot niż to umundurowanie. 

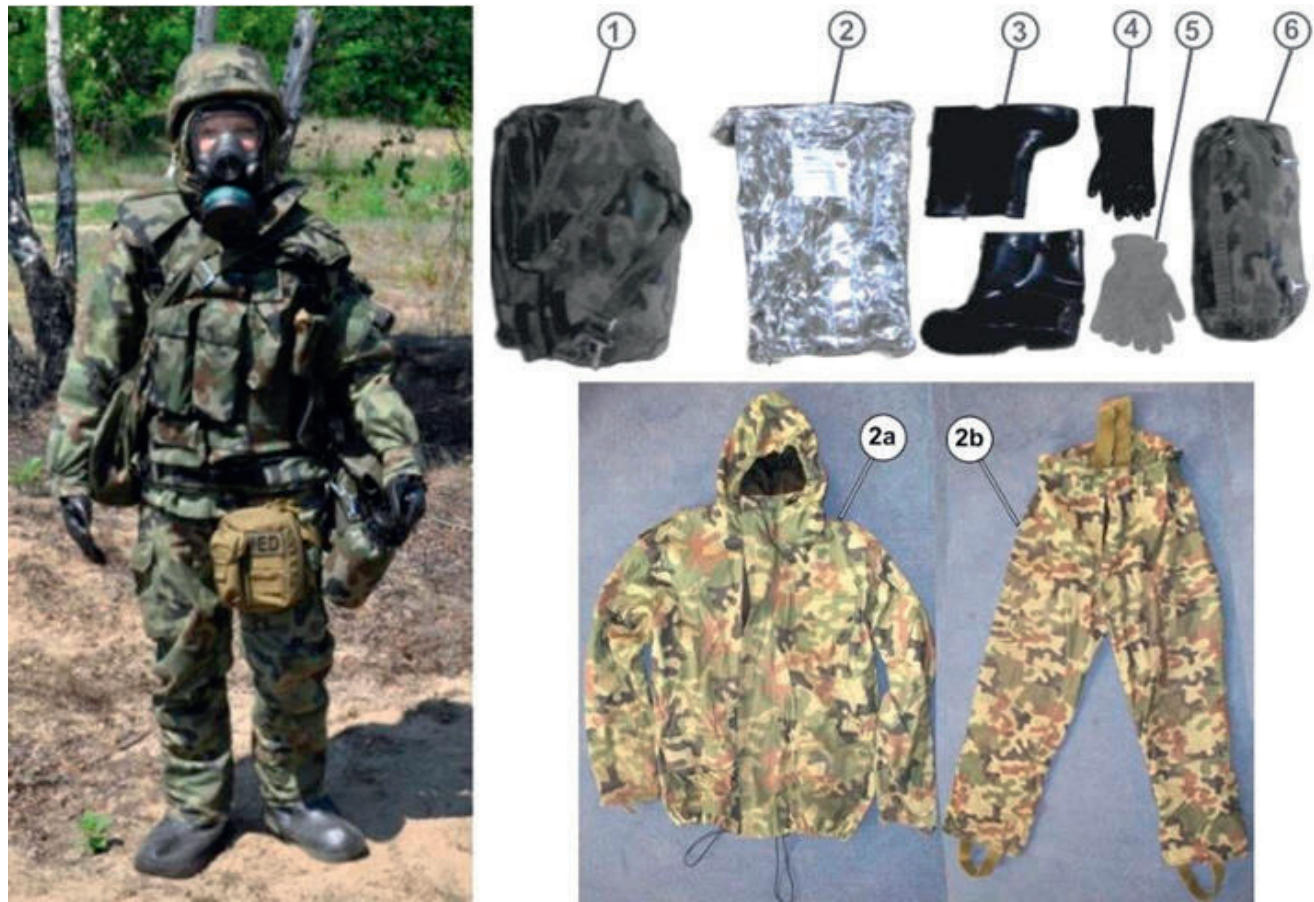

Ryc. 4. Filtracyjna odzież ochronna FOO-1

1 - zasobnik na komplet odzieży, 2 - opakowanie hermetyczne z odzieżą ochronną, 2a - kurtka z kapturem, 2b - spodnie, 3 - buty ochronne, 4 - rękawice ochronne, 5 - rękawice ocieplające, 6 - torba nośna na buty i rękawice ochronne

Fig. 4 . Filter clothing

1 - set of clothing tray, 2 - hermetic package with protective clothing, $2 \mathrm{a}$ - hooded sweatshirt, $2 \mathrm{~b}$ - trousers, 3 - safety shoes, 4 - protective gloves, 5 - warming gloves, 6 - carrier bag for shoes and gloves

Źródło: Opracowanie własne.

Source: Own elaboration.

Dane techniczne FOO-1:

- czas bezpiecznego przebywania w atmosferze skażonej - 24 godziny,

- okres przydatności do użycia po wyjęciu z opakowania hermetycznego - do $30 \mathrm{dni}$,

- maksymalna liczba cykli zamoczenie - suszenie, w tym pranie - do 6 razy,

- czas ochrony:

- przed parami iperytu - 24 godziny,

- przed kroplami iperytu - 8 godzin.

Ubranie uszyte jest $\mathrm{z}$ dwuwarstwowej tkaniny: warstwę wewnętrzną stanowi materiał filtrosorpcyjny, a wierzchnią - materiał w kolorze maskującym.

\subsubsection{Narzutka ochronna NO-1}

Narzutka w komplecie z filtracyjną odzieżą ochronną i maską przeciwgazową jest przeznaczona do ochrony żołnierza przed kroplami bojowych środków trujących, biologicznych oraz pyłem promieniotwórczym. Narzutka umożliwia żołnierzowi opuszczenie i przekroczenie strefy skażonej oraz realizację zadań bojowych w warunkach skażeń. Zapewnia także ochronę przed ciekłymi wysokotoksycznymi substancjami przemysłowymi, produktami ropopochodnymi oraz opadami atmosferycznymi.

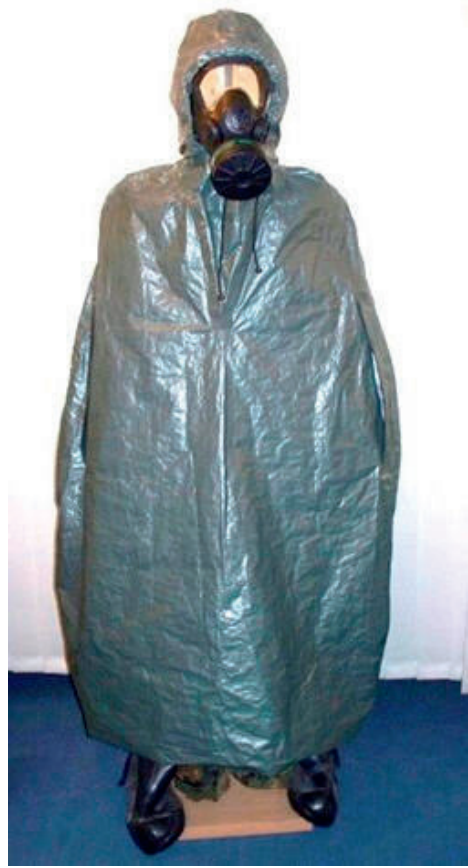

Ryc. 5. Narzutka ochronna NO-1

Fig. 5. Protective cape NO-1

Źródło: Opracowanie własne. Source: Own elaboration.

Narzutka jest ubiorem jednoczęściowym, typu peleryna, nakładanym przez głowę. Narzutka ma 
zintegrowany kaptur zaopatrzony w ściągacz ze stoperami. Budowa narzutki umożliwia jej nakładanie przez żołnierza z założoną maską przeciwgazową i hełmem. Z przodu narzutki znajdują się symetrycznie rozmieszczone otwory zabezpieczone patką, które służą do wyjmowania rąk z przestrzeni pod narzutką. Masa narzutki w opakowaniu wynosi w zależności od rozmiaru od 490 do 540 g. Narzutka ochronna NO-1 występuje w trzech rozmiarach różniących się długością.

Szczegółowe dane zamieszczono w Instrukcji eksploatacji filtracyjnej odzieży ochronnej FOO-1 i narzutki ochronnej NO-1, Chem. 410/2013.

\section{4. Środki do udzielania pierwszej pomocy}

Indywidualny pakiet medyczny żołnierza (IPMed) to kompletny pakiet, który umożliwia udzielenie pierwszej pomocy poszkodowanemu i wstępne opatrzenie ran oraz zatamowanie krwotoku do czasu dotarcia ratownika medycznego pododdziału lub ewakuacji na tyły. Opakowanie pakietu zostało wykonane z wodoodpornej tkaniny, a system taśm przewlekanych zapewnia jego zamocowanie do oporządzenia taktycznego zgodnego ze standardem MOLLE 40/25. Torba jest zamykana za pomocną grubego, dwusuwakowego zamka z system łatwego otwierania. Szczegółowe dane zamieszczono w instrukcji eksploatacji dostępnej na stronie internetowej Inspektoratu Wojskowej Służby Zdrowia: http://www.iwsz.wp.mil.pl/pl/71.html.

Pakiet IPMed obejmuje cztery elementy:

- panel udowy - z systemem służącym do mocowania i przenoszenia pakietu na udzie, pasie głównym lub kamizelce,

- pakiet w formie prostokątnego pokrowca o wymiarach $160 \times 130 \times 80 \mathrm{~mm}$,

- T-panel „wynośny” na medykamenty,

- pokrowiec do przenoszenia IZAS-05.

IPMed wyposażony jest $\mathrm{w}$ następujące środki medyczne:

- opatrunek indywidualny OLAES,

- opatrunek hemostatyczny CELOX Gauze,

- gaza wypełniająca (kompresowana),

- opaska uciskowa (staza taktyczna) Combat Application Tourniquet,

- opatrunek na rany penetracyjne klatki piersiowej Bolin Chest Seal (uszczelniający, zapobiegający powstawaniu odmy),

- rurka nosowo-gardłowa z żelem wodnym,

- plaster na rolce,

- nożyczki ratownicze,

- nitrylowe rękawice ratownicze,

- zestaw autostrzykawek.

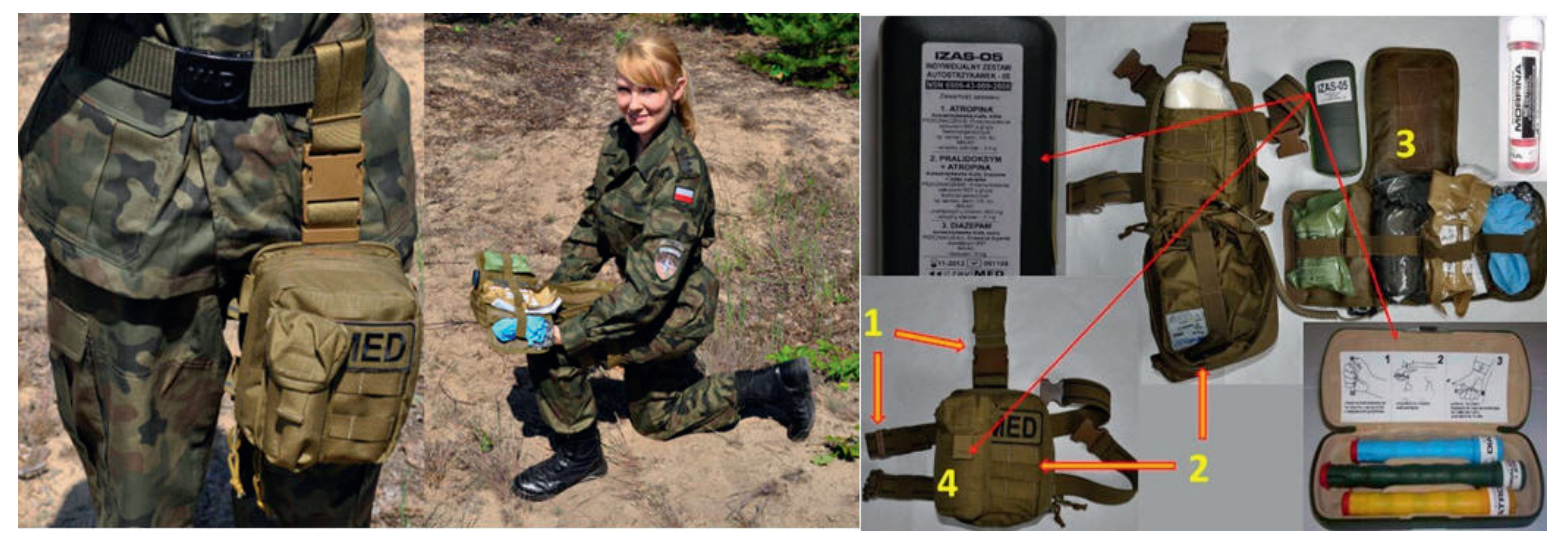

Ryc. 6. Indywidualny pakiet medyczny żołnierza IPMed

1 - panel udowy, 2- pakiet, 3 - T-panel, 4 - pokrowiec z IZAS-05

Fig. 6. Individual medical package of a soldier (IMEDP)

1 - femoral panel, 2 - package, 3 - T-panel, 4 - cover with IZAS-05

Źródło: Opracowanie własne.

Source: Own elaboration.

Indywidualny Zestaw Autostrzykawek IZAS-05 jest zestawem środków farmakologicznych przeciwdziałających skutkom zatrucia fosforoorganicznymi środkami trującymi i składa się z trzech autostrzykawek umieszczonych $\mathrm{w}$ pudełku $\mathrm{z}$ tworzywa sztucznego (ryc. 7):

- zielonej - przeznaczonej do przeciwdziałania zatruciom BST z grupy fosforoorganicznych, np.: soman, sarin, VX itp.; zawiera: pralidoksymu chlorek (reaktywtor AchE) - $600 \mathrm{mg}$, atropiny siarczan $-2 \mathrm{mg}$,

- żółtej - przeznaczonej do podtrzymania działania cholinolitycznego w zatruciach BST z grupy fosforoorganicznych (po podaniu autostrzykawki zielonej); zawiera atropiny siarczan (cholinolityk) - $2 \mathrm{mg}$,

- niebieskiej - przeznaczonej do zniesienia drgawek wywołanych BST; zawiera diazepam (środek uspokajający) $-10 \mathrm{mg}$. 


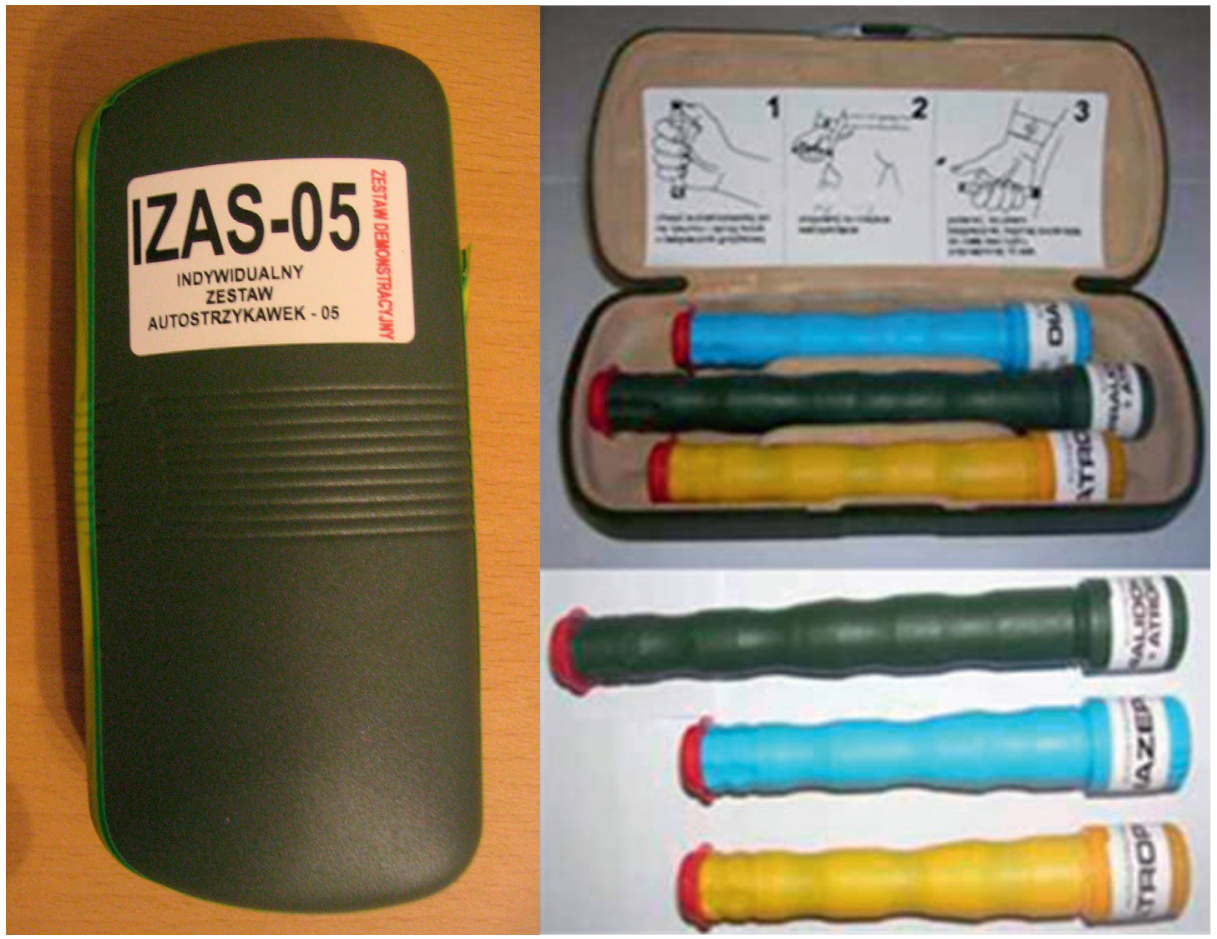

Ryc. 7. Indywidualny zestaw autostrzykawek IZAS-05

Fig. 7. An individual auto-injector kit IZAS-05

Źródło: Opracowanie własne oraz http://commons.wikimedia.org/wiki/File:IZAS_05.JPG. Source: Own elaboration and http://commons.wikimedia.org/wiki/File:IZAS_05.JPG.

Dodatkowo w wyposażeniu indywidualnym znajduje się autostrzykawka czerwona zawierająca $10 \mathrm{mg}$ morfiny będącej silnym środkiem przeciwbólowym (ryc. 8).
Szczegółowe dane zamieszczono w instrukcji eksploatacji dostępnej na stronie internetowej Inspektoratu Wojskowej Służby Zdrowia: http://www.iwsz.wp.mil.pl/pl/71.html.

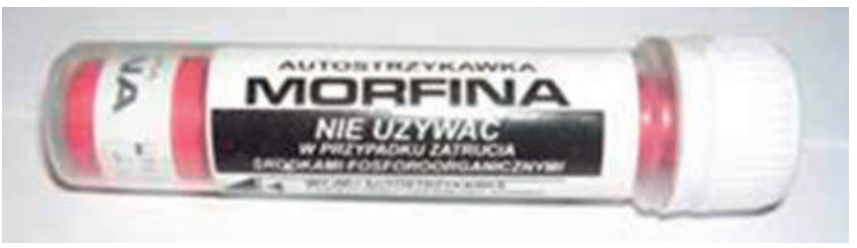

Ryc. 8. Autostrzykawka z morfiną

Fig. 8. An auto-injector with morphine

Źródło: Opracowanie własne.

Source: Own elaboration.

\subsection{Indywidualne pakiety do likwidacji skażeń}

Indywidualny pakiet przeciwchemiczny IPLS-1 wchodzi w skład indywidualnego wyposażenia żołnierza i zastępuje dotychczas używane pakiety IPP-95 i PChW-012. Pakiet przeznaczony jest do:

- profilaktycznego zabezpieczenia przed oddziaływaniem BST oraz do prowadzenia likwidacji skażeń odkrytych powierzchni skóry (twarz, dłonie, szyja), - prowadzenia likwidacji skażeń broni osobistej i wyposażenia.

W skład pakietu wchodzą trzy aktywne środki do likwidacji skażeń o różnym przeznaczeniu:

- maść profilaktyczna stosowana w przypadku zagrożenia skażeniem BST, do zabezpieczenia odkrytych powierzchni skóry przed skażeniem (na bazie kwasu nadoctowego, który jest źródłem silnie utleniającego tlenu rodnikowego),

- środek organiczny stosowany do likwidacji skażeń BST powierzchni metalowych uzbrojenia i wyposażenia (należy zachować ostrożność ze względu na jego łatwopalność oraz możliwość oparzenia skóry i uszkodzenia oczu),

- proszek stosowany do usuwania BST ze skażonej skóry i wyposażenia (wykorzystano m.in. zjawisko adsorpcji).

Szczegółowe dane zamieszczono $\mathrm{w}$ instrukcji fabrycznej. Jak dotychczas nie wydano instrukcji wojskowej. 


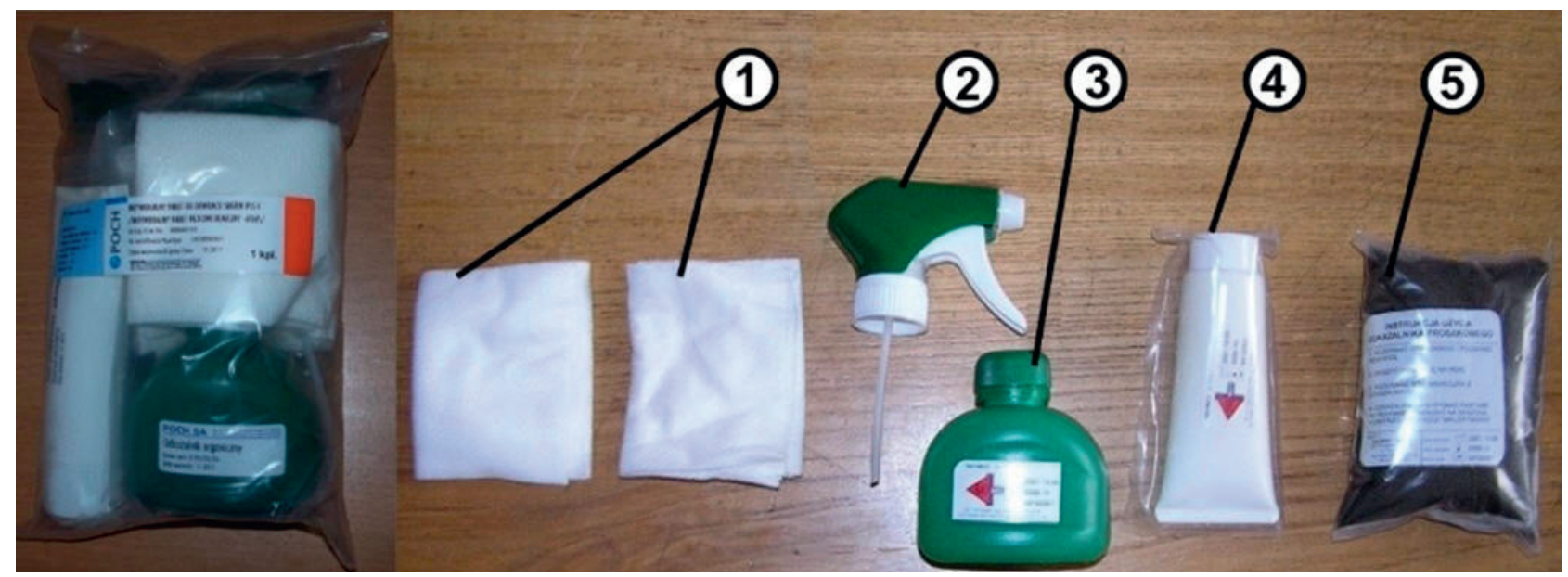

Ryc. 9. IPLS - 1: po lewej - w stanie złożonym, po prawej - rozłożony

1 - dwie serwety, 2 - głowica spryskiwacza z pompką, 3 - zbiornik spryskiwacza z ciekłym środkiem do likwidacji skażeń, 4 - tubka z tworzywa sztucznego z maścią profilaktyczną, 5 - pakiet $\mathrm{w}$ folii z proszkowym środkiem do likwidacji skażeń i rękawica

Fig. 9. IPLS - 1: left - in the assembled state, on the right - disassembled

1 - two napkins, 2 - head washer with pump, 3 - the spray tank with liquid decontamination agent, 4 - plastic tube prophylactic ointment, 5 - pack in foil with powder agent decontamination and the glove

Źródło: Opracowanie własne.

Source: Own elaboration.

\section{Podsumowanie i wnioski}

Pomimo faktu, iż Siły Zbrojne angażowane są w razie konieczności do wspierania działań służb cywilnych, należy pamiętać, że ich zasadniczym przeznaczeniem jest przeciwdziałanie zagrożeniom zewnętrznym. Z tego względu zasadnicza część aktywności wojsk w czasie pokoju skupia się na działalności szkoleniowej. Z powyższej przyczyny przedstawione możliwości sprzętu w znacznej mierze odpowiadają potrzebom zapewnienia bezpieczeństwa w sytuacji zagrożenia czynnikami rażenia BMR. Tym niemniej wydzielone siły i środki Sił Zbrojnych RP, w ramach Systemu Zarządzania Kryzysowego oraz Krajowego Systemu Wykrywania Skażeń i Alarmowania, prowadzą m.in. obserwację i monitoring sytuacji skażeń na terenie kraju oraz utrzymują potencjał do wsparcia służb cywilnych na wypadek wystąpienia sytuacji nadzwyczajnych. Co więcej, analiza aktualnych wyzwań oraz zagrożeń niejako zmusza do stawienia czoła terroryzmowi niekonwencjonalnemu, który coraz częściej postrzegany jest za najbardziej możliwy kierunek ewolucji tego zjawiska. Niezbędna jest zatem konieczność przygotowania i utrzymywania odpowiednich sił i środków ukierunkowanych na zapewnienie bezpieczeństwa powszechnego. Implikuje to dążenie do wzmocnienia potencjału krajowego ratownictwa w oparciu o istniejące siły i środki Systemu Zarządzania Kryzysowego, szczególnie w obliczu organizowanych imprez masowych w skali np. Euro 2012. Można więc pokusić się o sformułowanie swoistej filozofii przygotowania do połączonego reagowania kryzysowego, która zakłada prakseologiczne osiągnięcie optymalnego potencjału w tej dziedzinie poprzez racjonalne wykorzystanie istniejącego potencjału, zmodernizowanie jego części oraz stworzenie nowych, niezbędnych elementów oraz orientuje całość na realizację zadania. Przy uwzględnieniu w tej kwestii racjonalnego przejścia ze stanu istniejącego do pożądanego należy się opierać na tym, co już istnieje, jest właściwie ukształtowane i może służyć swoim doświadczeniem innym [10]. Takim elementem jest bez wątpienia Ratownictwo Chemiczne Sił Zbrojnych i Krajowy System Ratowniczo Gaśniczy. Obecnie celem nadrzędnym jest potrzeba uświadomienia sobie zbieżności zadań obu porównywanych podmiotów i w oparciu o istniejące uwarunkowania prawne, zasady i procedury działania oraz siły i środki stworzyć warunki do kompatybilnego i synergicznego działania wszystkich elementów wykonawczych reagowania kryzysowego. Z punktu widzenia prakseologii sytuacja ta stwarza dogodne warunki do efektywnego wzmocnienia systemu ratownictwa krajowego. 


\section{Literatura}

[1] Ustawa $\mathrm{z}$ dnia 26 kwietnia 2007 r. o zarządzaniu kryzysowym (Dz. U. 07 nr 89 z późn. zm.).

[2] Decyzja Nr Z-3/MON Ministra Obrony Narodowej z dnia 10 kwietnia 2006 r. w sprawie Systemu Zarządzania Kryzysowego resortu Obrony Narodowej.

[3] Decyzja Nr Z-1/MON Ministra Obrony Narodowej z dnia 15 lutego 2007 r. w sprawie Systemu Zarządzania Kryzysowego resortu obrony narodowej.

[4] Plan zarządzania kryzysowego Ministerstwa Obrony Narodowej z załącznikami, 2010.

[5] Maciejewski P., Pich R., Wrzesiński J., Specjalistyczne Grupy Ratownictwa Chemiczno-Ekologicznego Państwowej Straży Pożarnej - zadania i wyposażenie. Część II, „Zeszyty Naukowe WSOWL", Vol. 155 Issue 1, 2010.

[6] Maciejewski P., Pich R., Wrzesiński J., Specjalistyczne Grupy Ratownictwa Chemiczno-Ekologicznego
Państwowej Straży Pożarnej - zadania i wyposażenie. Część II, „Zeszyty Naukowe WSOWL”, Vol. 156 Issue 2, 2010.

[7] Rozkaz Szefa Sztabu Generalnego WP Nr 1273/ Oper./P7 z dnia 14 grudnia 2006 r. w sprawie funkcjonowania Podsystemu Ratownictwa Chemicznego w Siłach Zbrojnych RP.

[8] Rozkaz Dowódcy Wojsk Lądowych Nr 101 z dnia 20 marca 2007 r. w sprawie funkcjonowania Podsystemu Ratownictwa Chemicznego w Wojskach Lądowych.

[9] DD/3.8(A), Obrona Przed Bronią Masowego Rażenia w Operacjach Połączonych, Szkol. 869/2013.

[10] Polko R., Zadania Grom w walce $z$ terroryzmem, praca doktorska, AON, 2008.

[11] Indywidualny zestaw autostrzykawek - fotografia http://commons.wikimedia.org/wiki/ File:IZAS_05.JPG [Dostęp: marzec 2015].

ppłk dr inż. Paweł Maciejewski - absolwent Wyższej Szkoły Oficerskiej we Wrocławiu oraz Uniwersytetu i Politechniki Wrocławskiej, doktor chemii. Oficer wojsk chemicznych, starszy wykładowca Centrum Szkolenia Obrony przed Bronią Masowego Rażenia w SZ RP w Akademii Obrony Narodowej w Warszawie.

Zajmuje się:

- problematyką obrony przed bronią masowego rażenia w podsystemie militarnym i niemilitarnym;

- współpracą wojsk chemicznych i PSP w procesie likwidacji skażeń;

- fizykochemicznymi metodami rozdziału mieszanin.

płk dr inż. Waldemar Robak - absolwent Wyższej Szkoły Oficerskiej Wojsk Chemicznych w Krakowie i Politechniki Wrocławskiej, doktor chemii. Oficer wojsk chemicznych Centrum Szkolenia Wojsk Inżynieryjnych i Chemicznych im. gen. Jakuba Jasińskiego we Wrocławiu.

Zajmuje się:

- problematyką obrony przed bronią masowego rażenia w podsystemie militarnym i niemilitarnym;

- środkami i urządzeniami do likwidacji skażeń;

- modelowaniem efektów rozpuszczalnikowych w układach ekstrakcyjnych oraz ciekłych układach dwufazowych woda - rozpuszczalnik organiczny.

ppłk dr inż. Mariusz Młynarczyk - absolwent Wyższej Szkoły Oficerskiej Wojsk Łączności, Politechniki Warszawskiej oraz Akademii Obrony Narodowej, doktor nauk społecznych. Oficer wojsk chemicznych, starszy wykładowca Centrum Szkolenia Obrony przed Bronią Masowego Rażenia w SZ RP w Akademii Obrony Narodowej w Warszawie.

Zajmuje się:

- problematyką obrony przed bronią masowego rażenia w podsystemie militarnym i niemilitarnym;

- prognozowaniem i oceną sytuacji skażeń z wykorzystaniem procedur manualnych i narzędzi informatycznych;

- zarządzaniem ryzykiem. 